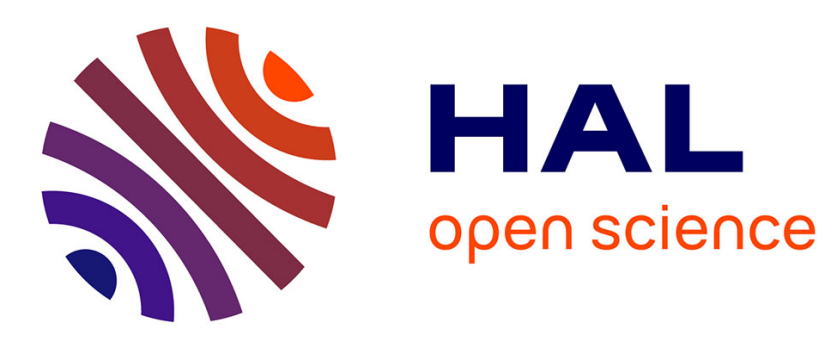

\title{
Free Ethylene Radical Polymerization under Mild Conditions: The Impact of the Solvent
}

Etienne Grau, Jean-Pierre Broyer, Christophe Boisson, Roger Spitz, Vincent Monteil

\section{- To cite this version:}

Etienne Grau, Jean-Pierre Broyer, Christophe Boisson, Roger Spitz, Vincent Monteil. Free Ethylene Radical Polymerization under Mild Conditions: The Impact of the Solvent. Macromolecules, 2009, 42 (19), pp.7279-7281. 10.1021/ma901622u . hal-00944969

\section{HAL Id: hal-00944969 https://hal.science/hal-00944969}

Submitted on 26 Nov 2019

HAL is a multi-disciplinary open access archive for the deposit and dissemination of scientific research documents, whether they are published or not. The documents may come from teaching and research institutions in France or abroad, or from public or private research centers.
L'archive ouverte pluridisciplinaire HAL, est destinée au dépôt et à la diffusion de documents scientifiques de niveau recherche, publiés ou non, émanant des établissements d'enseignement et de recherche français ou étrangers, des laboratoires publics ou privés. 


\title{
Free ethylene radical polymerization under mild conditions: the impact of the solvent
}

\author{
Etienne Grau, Jean-Pierre Broyer, Christophe Boisson, Roger Spitz, Vincent Monteil* \\ Université de Lyon, Univ. Lyon 1, CPE Lyon, CNRS UMR 5265
}

Laboratoire de Chimie Catalyse Polymères et Procédés (C2P2), LCPP team

Bat 308F, 43 Bd du 11 novembre 1918, F-69616 Villeurbanne, France.

*monteil@1cpp.cpe.fr

\begin{abstract}
Ethylene polymerization is performed industrially either by radical polymerization under severe conditions $\left(1000-4000\right.$ bar, $200-300^{\circ} \mathrm{C}$ ) or by catalytic mechanism at lower temperatures (usually less than $100^{\circ} \mathrm{C}$ ) and pressures (below 50 bar). Standard radical polymerization conditions are too severe to permit a fine control of the macromolecular architecture. Under milder conditions radical ethylene polymerization is assumed to be ineffective, which has been confirmed using toluene as solvent. The efficiency of free radical polymerization under mild conditions (up to 250 bar of ethylene and a polymerization temperature between $50^{\circ} \mathrm{C}$ to $90^{\circ} \mathrm{C}$ ) has been investigated in THF which is a more polar solvent than toluene. In this solvent, polyethylene has been obtained with relatively good yields highlighting an unexpected high solvent effect in the free radical ethylene polymerization. This solvent effect has been rationalized using theoretical considerations.
\end{abstract}


Ethylene is industrially polymerized either by radical polymerization under severe conditions or by catalytic polymerization at lower temperatures and pressures. Free radical polymerization of ethylene is performed under high pressure (1000-4000 bar) and high temperature $\left(200-300^{\circ} \mathrm{C}\right)$ in bulk. ${ }^{1,2}$ Under these conditions radical polymerization provides a branched polyethylene due to uncontrolled transfer reactions to polymer. Polymers possess a degree of crystallinity of $45-55 \%$ and melting points of $105-$ $115^{\circ} \mathrm{C}$. They contain 15-25 short-chain branches and 2-5 long-chain branches per 1000 carbon atoms. Catalytic polymerizations ${ }^{3,4}$ generally occur at low pressure (1-50 bar) and low temperature (near or below $\left.100^{\circ} \mathrm{C}\right)$. Under intermediate conditions $\left(100-200^{\circ} \mathrm{C}, 100-500\right.$ bar) an anionic oligomerization ${ }^{5,6}$ of ethylene ("Aufbau" reaction) occurs leading to a linear polyethylene with low molecular weight.

At ethylene pressure below 300 bar and low temperature $\left(<100^{\circ} \mathrm{C}\right)$ radical polymerization has been shown to be inefficient, unless ethylene is activated by strong Lewis acid such as original lithium cations. $^{7}$ Clark's calculations ${ }^{8,9}$ of the gas-phase activation energy of methyl radical addition to ethylene predicted a decrease from 60 to $25 \mathrm{~kJ} / \mathrm{mol}$ when ethylene is complexed with $\mathrm{Li}^{+}$.

The development of radical polymerization of ethylene under mild conditions $(\mathrm{P}<250$ bar and $50^{\circ} \mathrm{C}<\mathrm{T}<90^{\circ} \mathrm{C}$ ) is an important challenge since it may open a new field of radical ethylene polymerization allowing the use of solvents, organic additives and classical radical initiators such as diazo compounds. Solvent effects have been observed in radical polymerization with common vinyl monomers, ${ }^{10,11}$ although this effect remains tiny except for vinyl acetate. To our knowledge, the influence of the solvent has not been discussed for radical polymerization of ethylene. In the present paper, radical ethylene polymerization is reported using two solvents having different polarities: toluene and THF. The solvent influences on productivity and polyethylene molecular weight are discussed and rationalized.

Radical polymerization of ethylene was performed at $70^{\circ} \mathrm{C}$ in the range of 10 to 250 bar using $\mathrm{AIBN}$ as initiator in toluene (Figure 1). Toluene was chosen in a first approach as a typical solvent of the slurry catalytic polymerization of ethylene performed using similar conditions. 


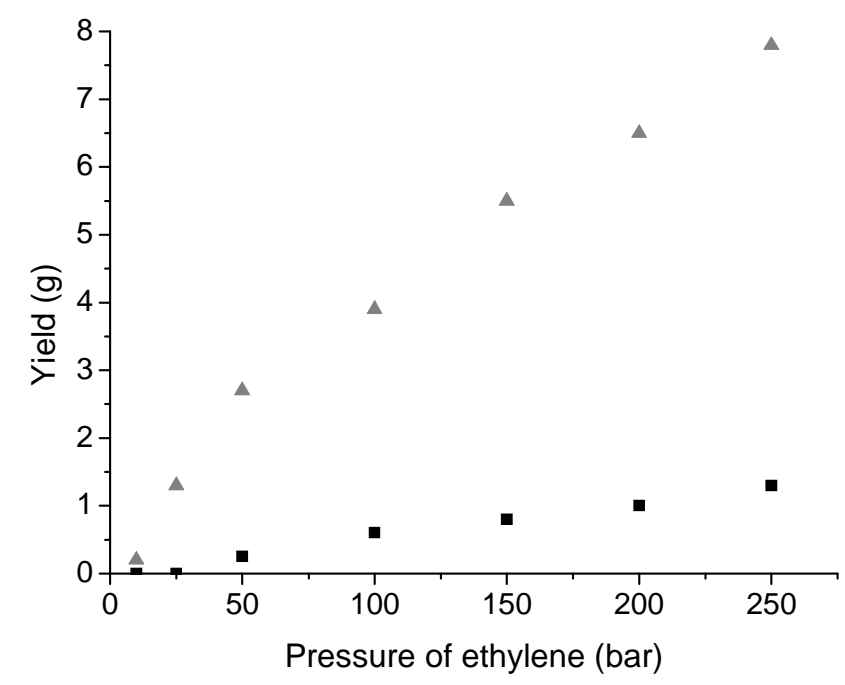

Figure 1: Pressure influence on ethylene radical polymerization

- : $50 \mathrm{mg}$ AIBN, $50 \mathrm{~mL}$ toluene $4 \mathrm{~h}$ at $70^{\circ} \mathrm{C}$ under ethylene pressure

$\triangle: 50 \mathrm{mg}$ AIBN, $50 \mathrm{~mL}$ THF $4 \mathrm{~h}$ at $70^{\circ} \mathrm{C}$ under ethylene pressure

Under 50 bar of ethylene pressure no polymer was obtained. From 50 to 250 bar polymerization occurred but conversion of ethylene remained very low (3\% conversion considering a solubility of ethylene $^{12}$ of $470 \mathrm{~g} / \mathrm{L}$ under 100 bar at $70^{\circ} \mathrm{C}$ ). As expected the radical polymerization of ethylene was inefficient under mild conditions using toluene as solvent.

We investigated ethylene polymerization in THF (typical solvent for radical polymerization), with the aim to improve yield. Surprisingly polymerization in THF occurred down to 10 bar of ethylene, an unusual pressure range for pure radical polymerization of ethylene. At 100 bar $3.9 \mathrm{~g}$ of polyethylene were isolated, corresponding to $17 \%$ of conversion. Radical polymerization of ethylene was about 6 times more efficient than in toluene. As already mentioned, solvent impact is usually a tiny effect in radical polymerization, but in the case of ethylene polymerization solvent seems to play a major role.

The produced polyethylenes were moderately branched in both solvents ( 7 branches/1000C in toluene and 9 branches/1000C in THF) as determined by ${ }^{13} \mathrm{C} \mathrm{NMR}^{13}$ (see supporting information Figures $\mathrm{S} 1$ and S2) and have a melting point between $115^{\circ} \mathrm{C}$ and $119^{\circ} \mathrm{C}$ and a crystallinity of $55-70 \%$ (see supporting 
information Table S1). ${ }^{13} \mathrm{C}$ NMR spectra showed only butyl and longer chain branches and no vinyl chain end. Transfer to solvent provided respectively phenyl-ended and THF-ended polyethylenes which were fully identified by ${ }^{13} \mathrm{C}$ NMR (see supporting information Figures S1 and S2). In the case of transfer to THF two different structures (1- and 2-polyethylenyl-THF, see supporting information Figure S2) were identified.

Molecular weights were lower in THF than in toluene. As expected molecular weights increased with ethylene concentration: from $950 \mathrm{~g} / \mathrm{mol}$ to $4300 \mathrm{~g} / \mathrm{mol}$ with toluene and from $440 \mathrm{~g} / \mathrm{mol}$ to $2400 \mathrm{~g} / \mathrm{mol}$ with THF. At pressure below 100 bar, melting points and molecular weights dropped (runs 3, 8-10) and oligomers were produced.

The number of chains per initiator was about 10 times higher in THF than in toluene. Molecular weights in THF were about 0.6 times lower than in toluene. Assuming AIBN dissociation being similar in both solvents, the rate of polymerization in THF was 6 times higher than in toluene.

To examine the variation of kinetic constants, the kinetic law of the free radical polymerization (equation 1) was checked for both toluene and THF solvents. We plotted $\ln (1 /(1-\mathrm{x}))$ versus time (Figure 2).

$$
\frac{1}{1-x} \frac{\partial x}{\partial t}=k_{p} \sqrt{\frac{2 f k_{d}[I]}{k_{t}}}=\mathrm{k}_{\mathrm{tot}}
$$

With: $x$ ethylene conversion, [I] AIBN concentration, f efficiency factor of the initiator, $k$ kinetic constants of initiator dissociation $(\mathrm{kd})$, propagation $(\mathrm{kp})$ and termination $(\mathrm{kt})$. 


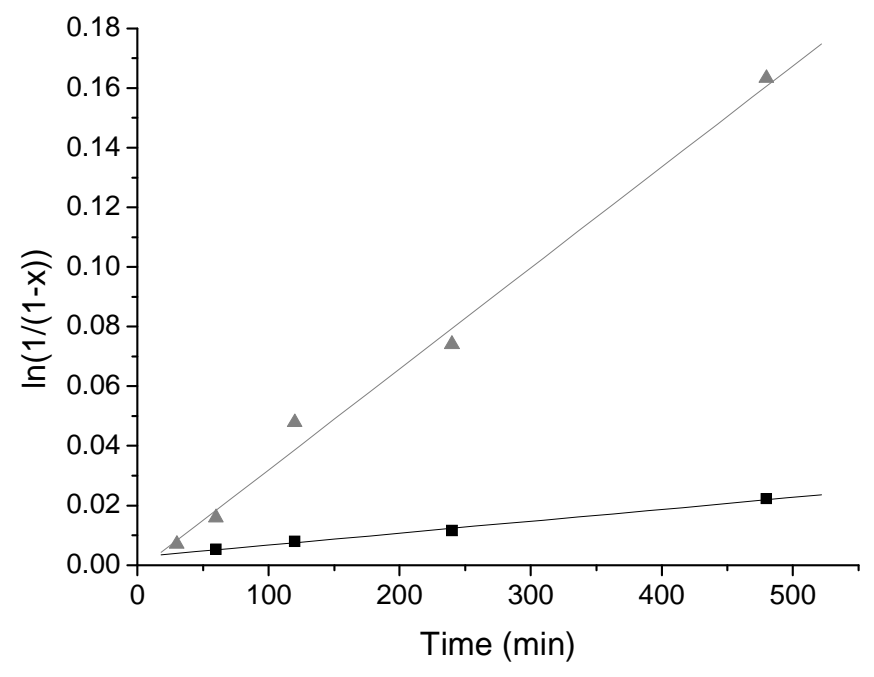

Figure 2: Influence of time on radical polymerization of ethylene

- : $50 \mathrm{mg}$ AIBN, $50 \mathrm{~mL}$ toluene at $70^{\circ} \mathrm{C}$ under 100 bar of ethylene pressure

$\triangle: 50 \mathrm{mg}$ AIBN, $50 \mathrm{~mL}$ THF at $70^{\circ} \mathrm{C}$ under 100 bar of ethylene pressure

A linear relation with a good correlation was observed for polymerization in THF and toluene. The slope $\mathrm{k}_{\text {tot }}$ for THF was 6 times higher than the toluene one. After 8 hours under 100 bar of ethylene, 7.8 $\mathrm{g}$ of polyethylene were produced with THF as solvent (33\% of conversion) and only $1.3 \mathrm{~g}$ with toluene (5.5\% of conversion). A factor 6 was observed as expected.

For each solvent, there was neither significant change in the melting point nor in the molecular weight during the polymerization (see supporting information Table S2).

Various concentrations of initiator were evaluated at 100 bar of ethylene pressure and $70^{\circ} \mathrm{C}$ (see supporting information Figure S3, Table S3). We plotted $\ln (1 /(1-\mathrm{x}))$ versus []$^{1 / 2}$. Equation 1 was once again confirmed. As expected molecular weight decreased according to the concentration of initiator, due to an increase of the termination rate. Melting points remained unchanged between $115^{\circ} \mathrm{C}$ and $117^{\circ} \mathrm{C}$ 
To further investigate the THF effect, polymerizations of ethylene under 100 bar at $70^{\circ} \mathrm{C}$ were performed with different mixtures of THF and toluene as solvent (Figure 3).

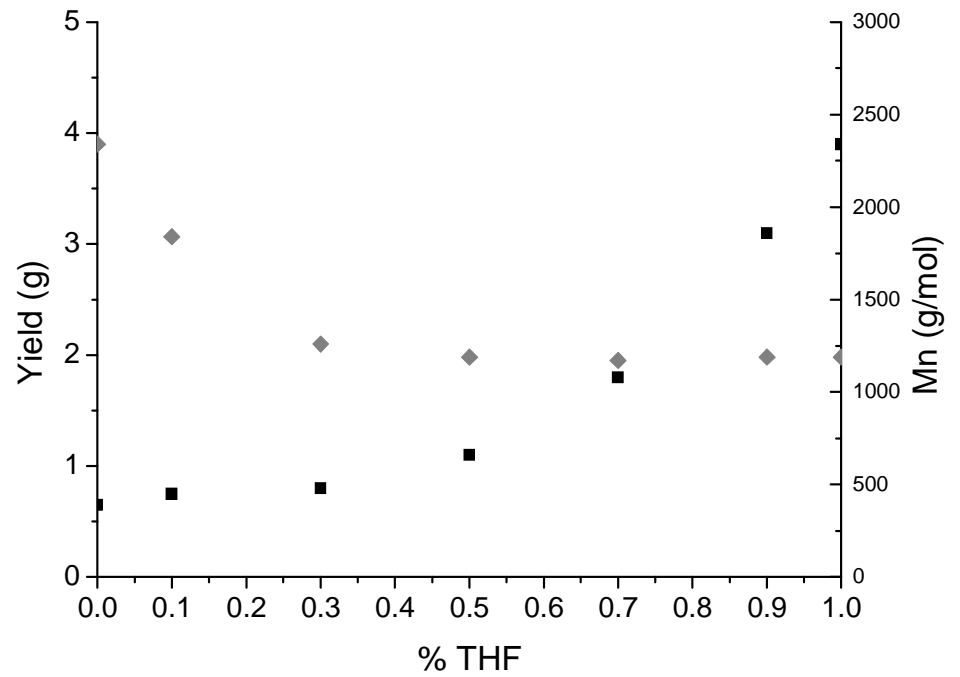

Figure 3: Impact of solvent composition on radical polymerization of ethylene

- : $50 \mathrm{mg}$ AIBN, $50 \mathrm{~mL}$ solvent, $4 \mathrm{~h}$ at $70^{\circ} \mathrm{C}$ under $100 \mathrm{bar}$ of ethylene pressure

$\checkmark$ : Mn (g/mol) determined using High Temperature SEC

Yield increased not linearly with the solvent composition. The observed activation was not proportional to the THF amount in the solvent mixture. Below $40 \%$ of THF the yield remained even and drastically increased over $40 \%$ of THF only. Molecular weights decreased with the addition of THF (see supporting information Table S4) due to transfer to THF.

\section{How to explain this unexpected effect of solvent?}

The THF activation can be explained by a change of polymerization rate. To go further we aim to calculate the global activation energy and global pre-exponential factor. For this purpose we performed polymerizations at several temperatures $\left(50^{\circ} \mathrm{C}, 70^{\circ} \mathrm{C}\right.$ and $90^{\circ} \mathrm{C}$ ) and ethylene pressures (from 50 bar up to 250 bar) in both solvents. One can remark that ethylene conversion seemed not to be linked to ethylene pressure (see supporting information table S5). At $90^{\circ} \mathrm{C}$ ethylene conversion reached $40 \%$ after 4 hours of polymerization. 
From these experiments we plotted $\mathrm{k}_{\text {tot }}$ versus $1 / \mathrm{T}$ to determine Arrhenius parameters. Corresponding $\mathrm{E}_{\mathrm{tot}}$ and $\ln \left(\mathrm{A}_{\mathrm{tot}}\right)$ are summarized in Table 1.

Table 1: Arrhenius parameters of ethylene polymerization (assuming the validity of Arrhenius law)

\begin{tabular}{ccc}
\hline Solvent & $\begin{array}{c}\mathbf{E}_{\text {tot }}-\text { Global activation } \\
\text { energy }(\mathbf{k J} / \mathbf{m o l})\end{array}$ & $\begin{array}{c}\mathbf{l n}\left(\mathbf{A}_{\text {tot }}\right)-\text { Global } \\
\text { preexponential factor }\end{array}$ \\
\hline Toluene & 27.7 & 7.6 \\
THF & 32.8 & 10.3 \\
\hline
\end{tabular}

Ideally, the determination of the Arrhenius parameters for each polymerization step should be performed, but this kind of study is currently incompatible with our conditions of pressure (since stopped flow or pulsed laser polymerizations techniques cannot be used).

$$
k_{t o t}=k_{p} \sqrt{\frac{2 f k_{d}[I]}{k_{t}}}=A_{t o t} \cdot \exp \left(\frac{-E_{t o t}}{R T}\right)\left\{\begin{array}{l}
E_{t o t}=E_{p}-\frac{1}{2} E_{t}+\frac{1}{2} E_{d} \\
A_{t o t}=A_{p} \sqrt{\frac{2 f A_{d}[I]}{A_{t}}}
\end{array}\right.
$$

The global activation energy (Equation 2a) and the pre-exponential factor (Equation 2b) are lower in toluene than in THF. Lower global activation energy is usually linked to a more favourable reaction. In both solvents the polymerization mechanism was considered to be the same, so the change in the global activation energy was only due to the relative stabilization of intermediate and activated states, which differ from one solvent to the other. ${ }^{14}$ Solubilization by toluene provides a lower energy barrier than in THF.

Despite lower global activation energy, toluene was less efficient than THF. The global preexponential factor is higher for THF, which explains, in the range of temperature used, the better efficiency of radical ethylene polymerization in THF. The global pre-exponential factor is proportional to the frequency of efficient shocks. With a higher pre-exponential factor the probability of the mechanism involved is supposed to increase. Differences in geometry of activated states in toluene and 
in THF could explain the difference of pre-exponential factors. Toluene is less electron donor than THF, more toluene molecules may therefore be necessary to stabilize the radical corresponding to a denser solvatation shell. This could explain a higher pre-exponential factor in THF than in toluene.

In summary, this work showed that radical ethylene polymerization can be effective under mild conditions $\left(50^{\circ} \mathrm{C}<\mathrm{T}<90^{\circ} \mathrm{C}\right.$ and $\mathrm{P}>10$ bar in $\left.\mathrm{THF}\right)$ contrary to what used to be assumed. The polymerization was 6 times more productive in THF than in toluene: conversions of ethylene up to $40 \%$ were obtained. Due to transfer to solvent, 1- or 2-polyethylenyl-THF were synthesized. Calculations of Arrhenius parameters have been done to understand THF activation. THF efficiency is not due to a lower global activation energy but to a higher pre-exponential factor corresponding to a higher efficient shock frequency. Further investigations with other solvents of various polarities are under progress in order to discriminate the solvent effect and to increase polyethylene molecular weights by reducing the transfer capacity of solvent. 
Acknowledgment: E.G. thanks the "Ministère de la Recherche et de l'Enseignement Supérieur" for fellowship.

Supporting Information Available: Experimental details, Polymerizations results, NMR measurements. This material is available free of charge via the Internet at http://pubs.acs.org

\section{References and Notes}

(1) Doak, K.W. In Encyclopedia of Polymer Science and Engineering, 2nd ed.; Mark, H. F.; Bikales, N. M.; Overberger, C. G.; Menges, G., Eds ; WileyInterscience: New York, 1985; Vol. 6, p 386-428.

(2) Aggarwal, S. L.; Sweeting, O. J. Chem. Rev. 1957, 57, 665-742.

(3) Mulhaupt, R. Macromol. Chem. Phys. 2003, 204, 289-327.

(4) Beach, D.L.; Kissin, Y.V. In Encyclopedia of Polymer Science and Engineering, 2nd ed.; Mark, H. F.; Bikales, N. M.; Overberger, C. G.; Menges, G., Eds ; WileyInterscience: New York, 1985; Vol. 6, p 454-489.

(5) Ziegler, K.; Gellert, H.-G.; Holzkamp, E.; Wilke, G. Angew. Chem. 1955, 67, 425.

(6) Ziegler, K.; Gellert, H.-G. Angew. Chem. 1952, 64, 323.

(7) Vyakaranam, K.; Babour, J. B.; Michl, J. J. Am. Chem. Soc. 2006, 128, 5610-5611.

(8) Horn, A. H. C.; Clark, T. J. Chem. Soc. Chem Commun 1986, 1774

(9) Horn, A. H. C.; Clark, T. J. Am. Chem. Soc. 2003, 125, 2809.

(10) Kamachi, M. Adv. Polym. Sci. 1981, 38, 55-87.

(11) Beuermann, S.; Buback, M. Prog. Polym .Sci. 2002, 27, 191-254. 
(12) Solubilization is a low kinetic process in absence of stirring. Thus to calculate the ethylene solubility in a solvent we charged the reactor with ethylene pressure without stirring and we recorded the pressure and temperature until the equilibrium under stirring. The difference in density between the initial step and the equilibrium gave us the solubilization of ethylene. Identical solubilities were estimated for toluene and THF.

(13) Galland, G. B.; de Souza, R. F.; Mauler, R. S.; Nunes, F. F. Macromolecules 1999, 32, 16201625 .

(14) Reichardt, C., In Solvents and solvent effects in organic chemistry, 2nd ed.; Reichardt, C. Ed.; VCH:Weinheim 1988; p 121-205. 
For Table of Contents Graphic only

Free ethylene radical polymerization under mild conditions: the impact of the solvent

Etienne Grau, Jean-Pierre Broyer, Christophe Boisson, Roger Spitz, Vincent Monteil*

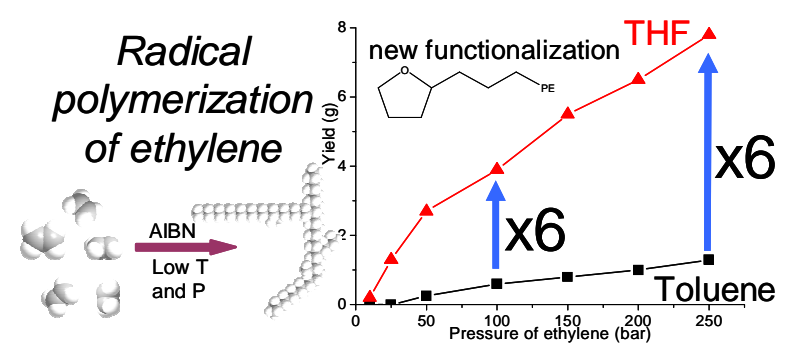




\section{Supporting Information}

Free ethylene radical polymerization under mild conditions: the impact of the solvent

Etienne Grau, Jean-Pierre Broyer, Christophe Boisson, Roger Spitz, Vincent Monteil*

\section{Experimental section}

All chemicals were purified using standard Schlenk procedures and handled under argon atmosphere. Anhydrous solvents were used in the reactions. Solvents were distilled from drying agents or degassed under argon. Ethylene was purchased from Air Liquide and AIBN from Acros.

\section{Characterizations}

Molecular weights of polyethylenes were determined by size exclusion chromatography (SEC) using a Waters Alliance GPCV 2000 instrument (columns: PLgel Olexis); two detectors (viscosimeter and refractometer) in trichlorobenzene (flow rate: $1 \mathrm{~mL} / \mathrm{min}$ ) at $150^{\circ} \mathrm{C}$. The system was calibrated with polystyrene standards using universal calibration. Differential scanning calorimetry (DSC) was performed on a Mettler Toledo DSC1 at a heating rate of $5 \mathrm{~K} / \mathrm{min}$. Two successive heating and cooling of the samples were performed. We have considered data (Tm values, crystallinity) obtained during the second heats. Highresolution liquid NMR spectroscopy was carried out with a Bruker DRX 400 or DRX 300 spectrometers operating at $400 \mathrm{MHz}$ or $300 \mathrm{MHz}$ for ${ }^{1} \mathrm{H}$. Spectra were obtained with a 5-mm QNP probe. PE samples were examined as 10-15\%(w/v) solutions using a mixture of tetrachloroethylene (TCE) and perdeuterobenzene $\left(\mathrm{C}_{6} \mathrm{D}_{6}\right)(2 / 1 \mathrm{v} / \mathrm{v})$ as solvent at $363 \mathrm{~K}$. Chemical shift values $(\delta)$ are given in ppm in reference to internal tetramethylsilane (TMS). 


\section{Standard polymerization}

Caution, all polymerizations involve high pressure and explosive gaz.

Ethylene polymerizations were done in a $160 \mathrm{~mL}$ stainless steel autoclave (equipped with safety valves, stirrer, oven) from Parr Instrument Co. . The azobisisobutyronitrile (AIBN) was dissolved in $50 \mathrm{~mL}$ of solvent in a Schlenk tube under argon. The mixture was introduced through cannula into the reactor. Ethylene was introduced and the mixture was heated at the desired temperature under stirring (300 rpm). To manage safely polymerization over 50 bar of ethylene we use a $1.5 \mathrm{~L}$ intermediate tank. The tank was cold down to $-20^{\circ} \mathrm{C}$ to liquefy ethylene at 35 bar. When thermodynamic equilibrium was reached, the intermediate tank was isolated and heated to reach $300 \mathrm{bar}$. This tank was used to charge the reactor. After 4 hours the reactor was slowly cooled down and degassed. The polymer was then dried under vacuum. 


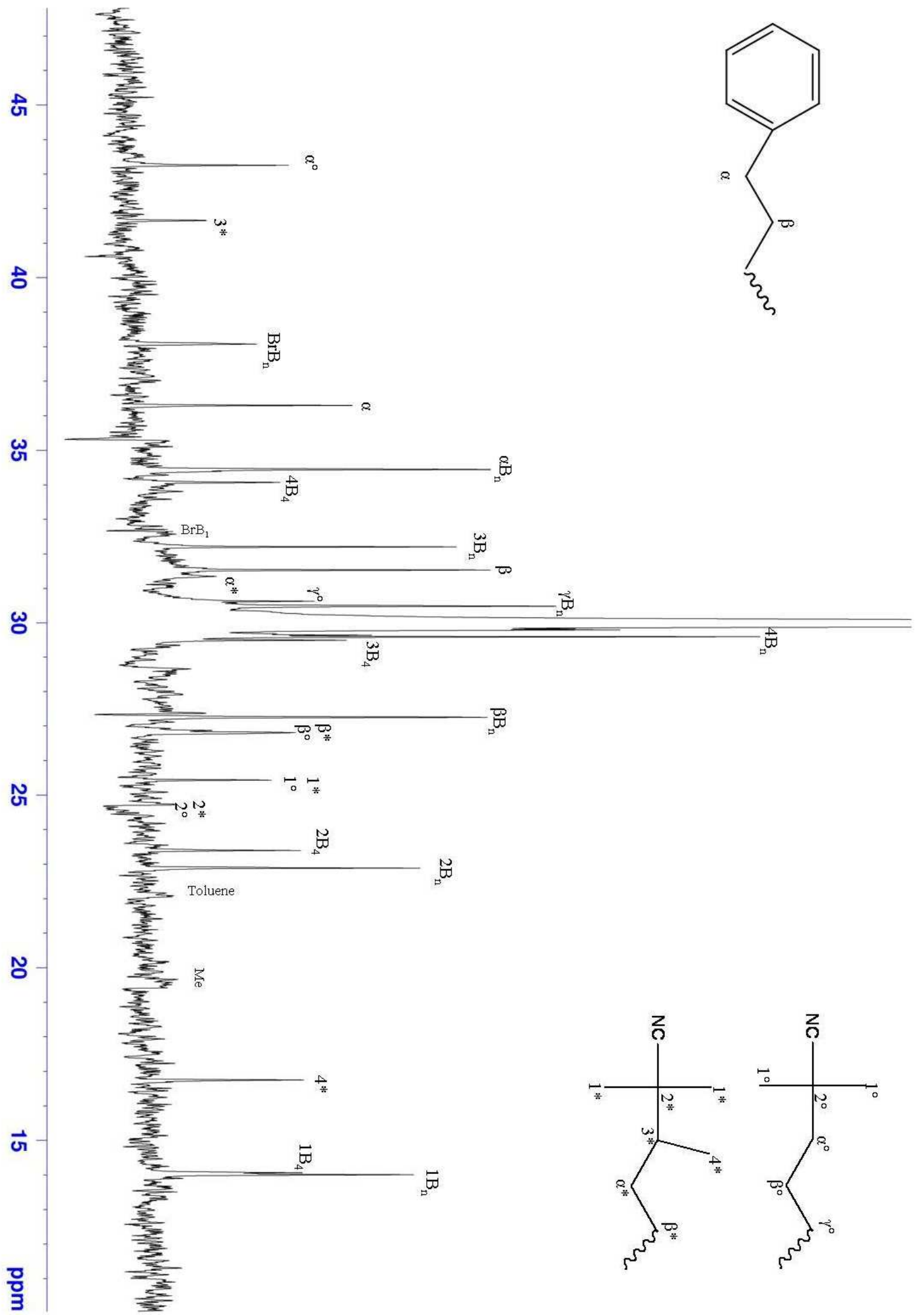

Figure S1: Typical ${ }^{13} \mathrm{C}$ NMR of polyethylene prepared in toluene (notation from Galland et al ref 13 of the article) 


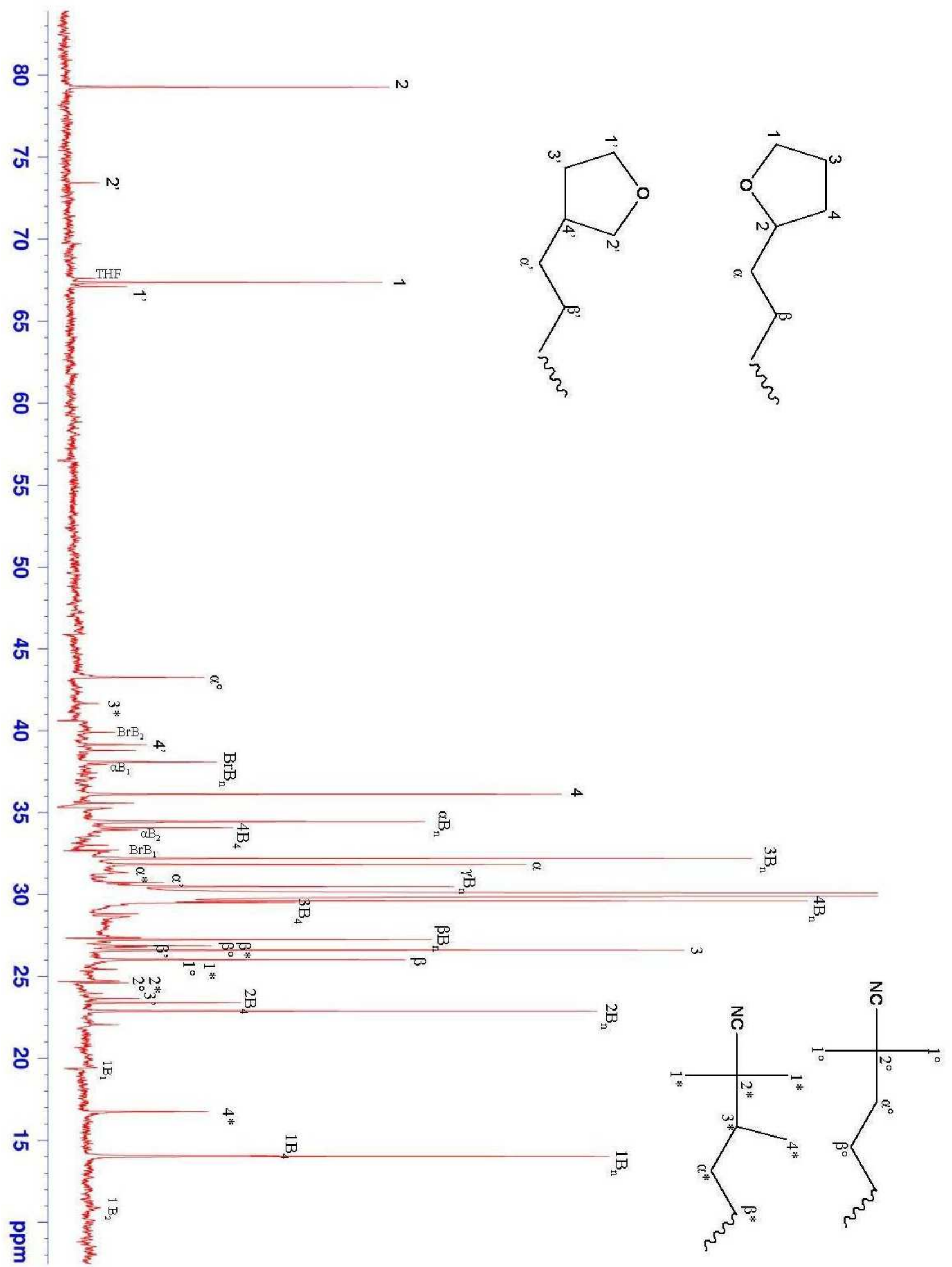

Figure S2: Typical ${ }^{13} \mathrm{C}$ NMR of polyethylene prepared in THF (notation from Galland et al) 


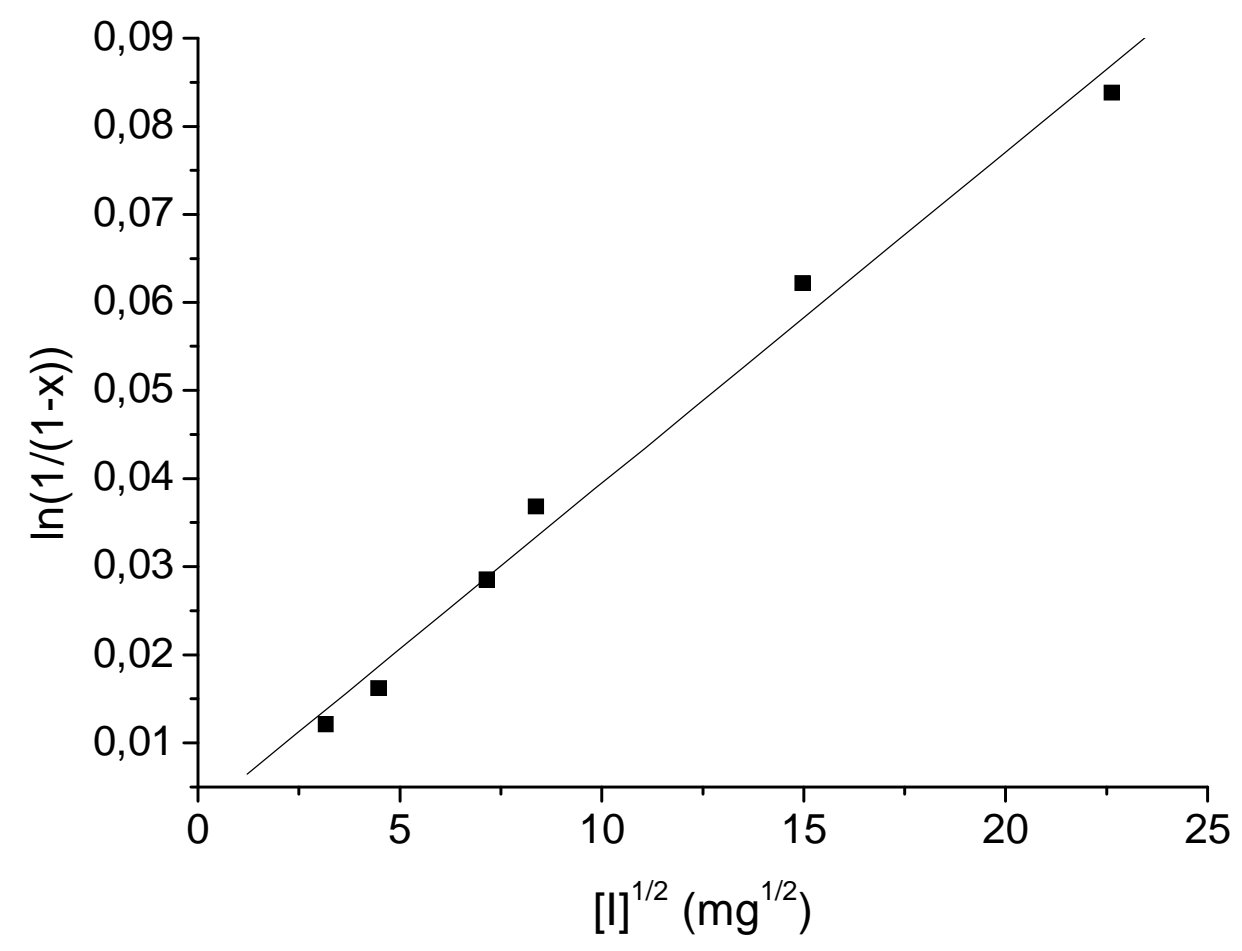

Figure S3: Influence of initiator concentration on radical polymerization of ethylene

- $50 \mathrm{~mL}$ toluene, $4 \mathrm{~h}$ at $70^{\circ} \mathrm{C}$ under 100 bar of ethylene pressure 
Table S1 : Influence of ethylene pressure

\begin{tabular}{cccccccc}
\hline Run & Solvent & $\begin{array}{c}\text { Pressure } \\
(\mathbf{b a r})\end{array}$ & $\begin{array}{c}\text { Yield } \\
(\mathbf{g})\end{array}$ & $\begin{array}{c}\text { Meltings } \\
\text { point }\left({ }^{\circ} \mathbf{C}\right)\end{array}$ & $\begin{array}{c}\text { Crystallinity } \\
(\%)\end{array}$ & $\begin{array}{c}\text { Mn } \\
(\mathbf{g} / \mathbf{m o l})\end{array}$ & PDI \\
\hline 1 & Toluene & 10 & 0 & - & - & - & - \\
2 & Toluene & 25 & 0 & - & - & - & - \\
3 & Toluene & 50 & 0.25 & 105.9 & 49 & 950 & 1.74 \\
4 & Toluene & 100 & 0.65 & 115.9 & 63 & 2340 & 1.92 \\
5 & Toluene & 150 & 0.8 & 118.3 & 56 & 2900 & 1.86 \\
6 & Toluene & 200 & 1.0 & 118.4 & 58 & 2990 & 1.90 \\
7 & Toluene & 250 & 1.3 & 118.7 & 66 & 4320 & 1.75 \\
8 & THF & 10 & 0.2 & - & - & 440 & 1.27 \\
9 & THF & 25 & 1.3 & 79.0 & 9 & 640 & 1.30 \\
10 & THF & 50 & 2.7 & 99.0 & 40 & 600 & 1.62 \\
11 & THF & 100 & 3.9 & 115.2 & 58 & 1190 & 1.86 \\
12 & THF & 150 & 5.5 & 115.5 & 57 & 1100 & 2.05 \\
13 & THF & 200 & 6.5 & 115.5 & 67 & 1720 & 1.83 \\
14 & THF & 250 & 7.8 & 115.6 & 72 & 2410 & 1.99 \\
\hline
\end{tabular}

Reactions were carried at $70^{\circ} \mathrm{C}$ under ethylene pressure during $4 \mathrm{~h}$ with $50 \mathrm{mg}$ AIBN in 50 $\mathrm{mL}$ of solvent 
Table S2 : Influence of polymerization time

\begin{tabular}{cccccccc}
\hline Run & Solvent & Time $(\mathbf{h})$ & $\begin{array}{c}\text { Yield } \\
(\mathbf{g})\end{array}$ & $\begin{array}{c}\text { Meltings } \\
\text { point }\left({ }^{\circ} \mathbf{C}\right)\end{array}$ & $\begin{array}{c}\text { Crystallinity } \\
(\%)\end{array}$ & $\begin{array}{c}\text { Mn } \\
(\mathbf{g} / \mathbf{m o l})\end{array}$ & PDI \\
\hline 15 & Toluene & 0.5 & 0 & - & - & - & - \\
16 & Toluene & 1 & 0.3 & 117.7 & 63 & 3410 & 1.98 \\
17 & Toluene & 2 & 0.45 & 118 & 62 & 2470 & 2.11 \\
$18(4)$ & Toluene & 4 & 0.65 & 115.9 & 63 & 2340 & 1.92 \\
19 & Toluene & 8 & 1.25 & 115.4 & 58 & 1740 & 2.50 \\
20 & THF & 0.5 & 0.4 & 113.3 & 55 & nd & nd \\
21 & THF & 1 & 0.9 & 114 & 63 & nd & nd \\
22 & THF & 2 & 2.9 & 113.9 & 67 & nd & nd \\
$23(11)$ & THF & 4 & 3.9 & 115.2 & 58 & 1190 & 1.86 \\
24 & THF & 8 & 7.8 & 109.9 & 47 & nd & nd \\
\hline
\end{tabular}

Reactions were carried at $70^{\circ} \mathrm{C}$ under 100 bar of ethylene with $50 \mathrm{mg}$ AIBN in $50 \mathrm{~mL}$ of solvent 
Table S3 : Influence of the concentration of initiator on radical polymerization of ethylene

\begin{tabular}{ccccccc}
\hline Run & AIBN (mg) & Yield (g) & $\begin{array}{c}\text { Meltings } \\
\text { point }\left({ }^{\circ} \mathbf{C}\right)\end{array}$ & Crystallinity (\%) & Mn (g/mol) & PDI \\
\hline 25 & 4 & 0 & - & - & - & - \\
26 & 10 & 0.3 & 116.5 & 53 & 2870 & 1.82 \\
27 & 20 & 0.4 & 115.9 & 58 & 2720 & 2.19 \\
$28(4)$ & 51 & 0.65 & 115.9 & 63 & 2340 & 1.92 \\
29 & 70 & 1.3 & 116.3 & 62 & 2120 & 2.08 \\
30 & 224 & 1.5 & 114.8 & 48 & 1900 & 1.71 \\
31 & 512 & 2 & 116.1 & 64 & 1630 & 2.46 \\
\hline
\end{tabular}

Reactions were carried at $70^{\circ} \mathrm{C}$ under 100 bar of ethylene during 4 hours in $50 \mathrm{~mL}$ of toluene 
Table S4 : Solvent composition impact on radical polymerization of ethylene

\begin{tabular}{|c|c|c|c|c|c|c|}
\hline Run & Solvent & $\begin{array}{l}\text { Yield } \\
\text { (g) }\end{array}$ & $\begin{array}{c}\text { Meltings } \\
\text { point }\left({ }^{\circ} \mathbf{C}\right)\end{array}$ & $\begin{array}{c}\text { Crystallinity } \\
(\%)\end{array}$ & $\begin{array}{c}\text { Mn } \\
(\mathrm{g} / \mathrm{mol})\end{array}$ & PDI \\
\hline $32(4)$ & $100 \%$ Toluene & 0.65 & 115.9 & 63 & 2340 & 1.92 \\
\hline 33 & $\begin{array}{c}90 \% \text { Toluene/ } \\
10 \% \text { THF }\end{array}$ & 0.75 & 116.4 & 63 & 1840 & 1.78 \\
\hline 34 & $\begin{array}{c}\text { 70\% Toluene/ } \\
30 \% \text { THF }\end{array}$ & 0.8 & 116.1 & 67 & 1260 & 2.03 \\
\hline 35 & $\begin{array}{l}50 \% \text { Toluene/ } \\
50 \% \text { THF }\end{array}$ & 1.1 & 114.7 & 62 & 1190 & 2.09 \\
\hline 36 & $\begin{array}{c}30 \% \text { Toluene/ } \\
70 \% \text { THF }\end{array}$ & 1.8 & 114.9 & 61 & 1170 & 2.07 \\
\hline 37 & $\begin{array}{l}\text { 10\% Toluene/ } \\
90 \% \text { THF }\end{array}$ & 3.1 & 114.8 & 60 & 1190 & 1.91 \\
\hline $38(11)$ & $100 \%$ THF & 3.9 & 115.2 & 58 & 1190 & 1.86 \\
\hline
\end{tabular}

Reactions were carried at $70^{\circ} \mathrm{C}$ under 100 bar of ethylene during 4 hours with $50 \mathrm{mg}$ AIBN in $50 \mathrm{~mL}$ of solvent 
Table S5 : Temperature impact on radical polymerization of ethylene

\begin{tabular}{|c|c|c|c|c|c|}
\hline Run & Solvent & $\begin{array}{c}\text { Temperature } \\
\left({ }^{\circ} \mathbf{C}\right)\end{array}$ & $\begin{array}{l}\text { Ethylene } \\
\text { pressure } \\
\text { (bar) }\end{array}$ & $\begin{array}{c}\text { Yield (g) } \\
\text { [conversion \%] }\end{array}$ & $\begin{array}{c}\text { Meltings point }\left({ }^{\circ} \mathbf{C}\right) \\
\text { [Crystallinity \%] }\end{array}$ \\
\hline 39 & Toluene & 50 & 50 & $0.05[0.5 \%]$ & - \\
\hline $40(3)$ & Toluene & 70 & 50 & $0.25[2.7 \%]$ & 105.9 [49\%] \\
\hline 41 & Toluene & 90 & 50 & $0.4[4.8 \%]$ & $99.2[36 \%]$ \\
\hline 42 & Toluene & 50 & 100 & $0.15[0.4 \%]$ & $117.5[76 \%]$ \\
\hline $43(4)$ & Toluene & 70 & 100 & $0.65[2.6 \%]$ & 115.9 [63\%] \\
\hline 44 & Toluene & 90 & 100 & $1.3[6.5 \%]$ & 112.2 [38\%] \\
\hline 45 & Toluene & 50 & 150 & $0.15[0.4 \%]$ & - \\
\hline $46(5)$ & Toluene & 70 & 150 & $0.8[2 \%]$ & 118.3 [56\%] \\
\hline 47 & Toluene & 90 & 150 & $1.7[5.2 \%]$ & $114.8[65 \%]$ \\
\hline 48 & Toluene & 50 & 200 & $0.2[0.4 \%]$ & $118.1[59 \%]$ \\
\hline $49(6)$ & Toluene & 70 & 200 & $1[2.1 \%]$ & $118.4[58 \%]$ \\
\hline 50 & Toluene & 90 & 200 & $2[4.8 \%]$ & $115.7[60 \%]$ \\
\hline 51 & Toluene & 50 & 250 & $0.25[0.4 \%]$ & - \\
\hline $52(7)$ & Toluene & 70 & 250 & $1.3[2.5 \%]$ & $118.7[66 \%]$ \\
\hline 53 & Toluene & 90 & 250 & $2.5[5.3 \%]$ & 117.8 [71\%] \\
\hline 54 & THF & 50 & 50 & 0.4 [3.7\%] & $106.4[52 \%]$ \\
\hline $55(10)$ & THF & 70 & 50 & $2.9[31.2 \%]$ & 99 [40\%] \\
\hline 56 & THF & 90 & 50 & $4.1[49.4 \%]$ & $56.2[-]$ \\
\hline 57 & THF & 50 & 100 & $0.6[1.8 \%]$ & $116.4[68 \%]$ \\
\hline $58(11)$ & THF & 70 & 100 & $3.9[15.7 \%]$ & $115.2[58 \%]$ \\
\hline 59 & THF & 90 & 100 & 9 [44.7\%] & 108.2 [49\%] \\
\hline 60 & THF & 50 & 150 & $0.8[1.7 \%]$ & $117.7[68 \%]$ \\
\hline
\end{tabular}




\begin{tabular}{cccccc}
$61(12)$ & THF & 70 & 150 & $5.9[15 \%]$ & $115.5[57 \%]$ \\
62 & THF & 90 & 150 & $11[33.6 \%]$ & $108.9[57 \%]$ \\
63 & THF & 50 & 200 & $1[1.9 \%]$ & $117.8[71 \%]$ \\
$64(13)$ & THF & 70 & 200 & $6.5[13.8 \%]$ & $115.5[67 \%]$ \\
65 & THF & 90 & 200 & $14.5[35 \%]$ & $106.8[50 \%]$ \\
66 & THF & 50 & 250 & $1.2[2.1 \%]$ & $118.8[78 \%]$ \\
$67(14)$ & THF & 70 & 250 & $7.8[14.9 \%]$ & $115.6[72 \%]$ \\
68 & THF & 90 & 250 & $17[35.9 \%]$ & $105.2[51 \%]$ \\
\hline $\begin{array}{c}\text { Reactions } \\
\text { of solvent }\end{array}$ & were carried under ethylene pressure during 4 hours with 50mg AIBN in 50 mL
\end{tabular}

